\title{
Cytoplasmic RNA-Binding Proteins and the Control of Complex Brain Function
}

\author{
Jennifer C. Darnell ${ }^{1}$ and Joel D. Richter ${ }^{2}$ \\ ${ }^{1}$ Department of Molecular Neuro-Oncology, Rockefeller University, New York, New York 10065 \\ ${ }^{2}$ Program in Molecular Medicine, University of Massachusetts Medical School, Worcester, Massachusetts \\ 01605 \\ Correspondence: darneje@mail.rockefeller.edu; joel.richter@umassmed.edu
}

The formation and maintenance of neural circuits in the mammal central nervous system (CNS) require the coordinated expression of genes not just at the transcriptional level, but at the translational level as well. Recent evidence shows that regulated messenger RNA (mRNA) translation is necessary for certain forms of synaptic plasticity, the cellular basis of learning and memory. In addition, regulated translation helps guide axonal growth cones to their targets on other neurons or at the neuromuscular junction. Several neurologic syndromes have been correlated with and indeed may be caused by aberrant translation; one important example is the fragile $X$ mental retardation syndrome. Although translation in the CNS is regulated by multiple mechanisms and factors, we focus this review on regulatory mRNAbinding proteins with particular emphasis on fragile $X$ mental retardation protein (FMRP) and cytoplasmic polyadenylation element binding (CPEB) because they have been shown to be at the nexus of translational control and brain function in health and disease.

$T^{\mathrm{h}}$ he integrated circuit that is the mammalian CNS controls complex cognitive processes such as learning, memory, and behavior. Synapses, the points of communication between neurons, are essential for closing this circuit. They are morphologically dynamic structures that respond to neurotransmitter stimulation by increasing or decreasing the strength of their response, a phenomenon referred to as synaptic plasticity. In the most basic sense, synapses are composed of pre- and postsynaptic compartments; presynaptic boutons are axonal substructures that transmit signals, whereas postsynaptic domains primarily occur on the dendrites and cell bodies of the neurons that receive these sig- nals. The adult presynaptic compartment generally lacks identifiable polysomes, suggesting that translation in this compartment is unlikely to play a substantial role in mature neuronal function. However, lack of detection of polysomes by electron microscopy is not proof of their absence, and indeed if only a few ribosomes are engaged with each messenger RNA (mRNA), then ultrastructural analysis may underestimate the translational capacity of this compartment. On the other hand, the postsynaptic compartment clearly contains polysomes, indicating that translation in this region could be important for higher-order brain activity (Steward and Levy 1982). Indeed, some forms of synaptic

Editors: John W.B. Hershey, Nahum Sonenberg, and Michael B. Mathews

Additional Perspectives on Protein Synthesis and Translational Control available at www.cshperspectives.org

Copyright (C) 2012 Cold Spring Harbor Laboratory Press; all rights reserved; doi: 10.1101/cshperspect.a012344

Cite this article as Cold Spring Harb Perspect Biol 2012;4:a012344 
plasticity, which comprise the underlying cellular basis of learning and memory, almost certainly require mRNA translation in the postsynaptic region (reviewed by Kandel 2001; Sutton and Schuman 2006; Richter and Klann 2009). Moreover, this translation is "local" because at least with Schaffer collateral CA1 neurons of the hippocampus, it takes place in the dendritic layer even when it is severed from the nucleuscontaining cell body (Kang and Schuman 1996; Huber et al. 2000). Translational control and RNA localization in neurons have been reviewed by a number of investigators (Holt and Bullock 2009; Wang et al. 2010; Doyle and Kiebler 2011); here, we focus on RNA-binding proteins as regulators of translation and complex brain function.

\section{TRANSLATIONAL REGULATION IN NEURONS}

It is now accepted wisdom that memory consolidation requires protein synthesis during a defined period relative to the training stimulus (Flexner et al. 1962; Flexner and Flexner 1968; Sutton and Schuman 2006). The foundation of this consolidation requires long-term changes in synaptic efficacy, measured electrophysiologically as long-term potentiation (LTP) or longterm depression (LTD), or ultrastructurally as shape changes in dendritic spines (Ostroff et al. 2002, 2010; Mishchenko et al. 2010; Dent et al. 2011). Before discussing particular mechanisms of translational control by RNA-binding proteins in neurons, however, synaptic plasticity should be placed into a molecular and cellular context that addresses not only how translation is regulated, but why. Consider that a typical neuron in the CNS may have thousands of synaptic inputs, yet when stimulated, the neuron can distinguish between experienced (stimulated) and naïve (unstimulated) synapses. How it does so has been a subject of intense investigation, but it is generally thought that the neuron "tags" the stimulated synapses, which results in changes in synaptic efficacy (Frey and Morris 1997). The nature of the tag may be complex, but at least in some circumstances, it involves de novo translation in dendrites. Thus, cellular memory, which when placed within a complex circuitry forms the basis for organismal memory, requires regulated translation. Moreover, certain stimulation protocols elicit changes in the synthesis of specific proteins (Scheetz et al. 2000), suggesting that general translational control mechanisms may not be sufficient for changes in plasticity. For reviews of the signaling pathways leading to changes in translation, see recent articles by Costa-Mattioli et al. (2009) and Hoeffer and Klann (2010).

\section{FMRP AND THE FRAGILE X SYNDROME}

Although the brain contains a multitude of mRNA-binding proteins, only a few have been shown to be required for proper neurologic function. Perhaps the most well known of these proteins is fragile $\mathrm{X}$ mental retardation protein (FMRP), the product of FMR1, the fragile $\mathrm{X}$ mental retardation syndrome gene. Individuals with the fragile $\mathrm{X}$ syndrome display a range of afflictions including epileptic-like cognitive deficits, autistic behaviors, epileptic-like seizures in childhood, and morphological anomalies such as elongated faces and large ears (Hagerman and Hagerman 2002; Penagarikano et al. 2007; Hagerman et al. 2009; Santoro et al. 2011). The syndrome is caused by a CGG triplet repeat expansion in the $5^{\prime}$ UTR of the FMR1 gene, resulting in abnormal DNA methylation and transcriptional silencing (Pieretti et al. 1991; Verkerk et al. 1991). FMRP is a complex RNA-binding protein that contains two KH (hnRNP K homology) domains and an RGG (arginine-glycine-glycine) box (Siomi et al. 1993), of which $\mathrm{KH} 2$ is perhaps the most critical for function (De Boulle et al. 1993; Zang et al. 2009). FMRP likely represses translation in dendrites as well as the cell body, yet when brain lysates are centrifuged through sucrose gradients, FMRP sediments with polysomes (Feng et al. 1997b; Khandjian et al. 2004; Stefani et al. 2004; Darnell et al. 2011), an unexpected association as translation is frequently repressed at the level of initiation and therefore most translational repressors are associated with mRNAs that are not polysome associated. The polyribosomal association of FMRP is dependent on the $\mathrm{KH} 2$ 
domain because a mutation in that region (I304N) abrogates RNA binding and polysome association (Feng et al. 1997a; Darnell et al. 2005a; Zang et al. 2009); as a consequence, expression of this nonfunctional protein elicits symptoms of the fragile $\mathrm{X}$ syndrome even when there is no CGG repeat (De Boulle et al. 1993). In addition, an I304N knockin mouse model also shows characteristics of the syndrome nearly identical to that of an FMRP knockout mouse (Zang et al. 2009). Taken together, these and other data indicate that the loss of FMRP function in regulating polysome-associated translational inhibition forms the molecular basis of the fragile $\mathrm{X}$ syndrome. It therefore follows that two keys for understanding the etiology of the syndrome lie with the identification of target mRNAs and the biochemical mechanism for their translational regulation.

The identification of mRNA targets and binding sites for RNA-binding proteins can be technically challenging processes. Two oftenused approaches are in vitro RNA selection (Ellington and Szostak 1990) (also known as SELEX, selective enrichment of ligands by exponential enrichment [Irvine et al. 1991]) or coimmunoprecipitation of protein-RNA complexes followed by microarray analysis or RT-PCR identification of specific transcripts (RIP-Chip) (Tenenbaum et al. 2000). Although often successful, these methods have their limitations; SELEXidentified sequences do not take into account the in vivo milieu that can help determine sequence specificity and RIP-Chip has been criticized for its low stringency and a high rate of both false positives and false negatives (Mukherjee et al.2011). To circumvent these issues, an in vivo UV cross-linking procedure (CLIP; when combined with high throughout sequencing, it is referred to as HITS-CLIP or CLIP-seq) has been devised that is highly specific with respect to both mRNA that is bound by a particular protein and the precise cis element that it recognizes (Ule et al. 2003; Licatalosi et al. 2008; Chi et al. 2009; Darnell et al. 2011; reviewed in Darnell 2010). HITS-CLIP uses UV irradiation to covalently link RNA-binding proteins and RNA, followed by stringent immunoprecipitation of the protein of interest, limited RNase digestion to reduce the size of the RNA that is "CLIPed," addition of linkers, and high-throughput sequencing (Fig. 1). The details of the procedure have been described elsewhere (Ule et al. 2005; Jensen and Darnell 2008), as has an outline of the advantages this method has over other techniques (Darnell 2010; Zhang and Darnell 2011). Suffice it to say that CLIP and subsequent modifications (Granneman et al. 2009; Hafner et al. 2010; Konig et al. 2010) have now been widely used to analyze several RNA-binding proteins from a number of tissues (Darnell 2010).

FMRP offers a particularly illustrative example of the power of CLIP and the results that can be obtained. Previously, in vitro SELEX analysis of FMRP had shown that the RGG box bound a G-quadruplex structure (Darnell et al. 2001, 2004) and KH2 bound a "kissing complex" (Darnell et al. 2005b). Moreover, RIP-Chip analysis from mouse brain found that the protein interacted with $\sim 430 \mathrm{mRNAs}$ (Brown et al. 2001). Application of the HITS-CLIP technique to polysome-associated FMRP revealed that FMRP interacted with a large and specific set of mRNAs highly enriched for those encoding components of both the pre- and postsynaptic compartments (Darnell et al. 2011). Interestingly, about half of the RIP-Chip-identified FMRP target mRNAs could not be confirmed by in vivo UV cross-linking, possibly illustrating the issue of false positives in the RIP-Chip assay (as in any method, CLIP may also have false positives as well). Moreover, only about a quarter of the $\sim 840$ FMRP UV cross-linked mRNAs were found by the RIP-Chip approach, indicating a high false negative rate for RIP-Chip, likely because of their loss during immunoprecipitation owing to the lack of a covalent bond between protein and RNA. In addition and quite surprisingly, the preponderance of FMRP-binding sites (CLIP sequence tags) resided in mRNA coding sequences, and not in $5^{\prime}$ or $3^{\prime}$ UTRs as might be expected based on analogy with other RNA-binding proteins such as the neuronal $\mathrm{Hu}$ family (Darnell et al. 2011). Moreover, FMRP interacted with its target mRNAs with an even distribution throughout the coding sequence, similar to the distribution of ribosomes, with no discernible preference for sequence or structural 


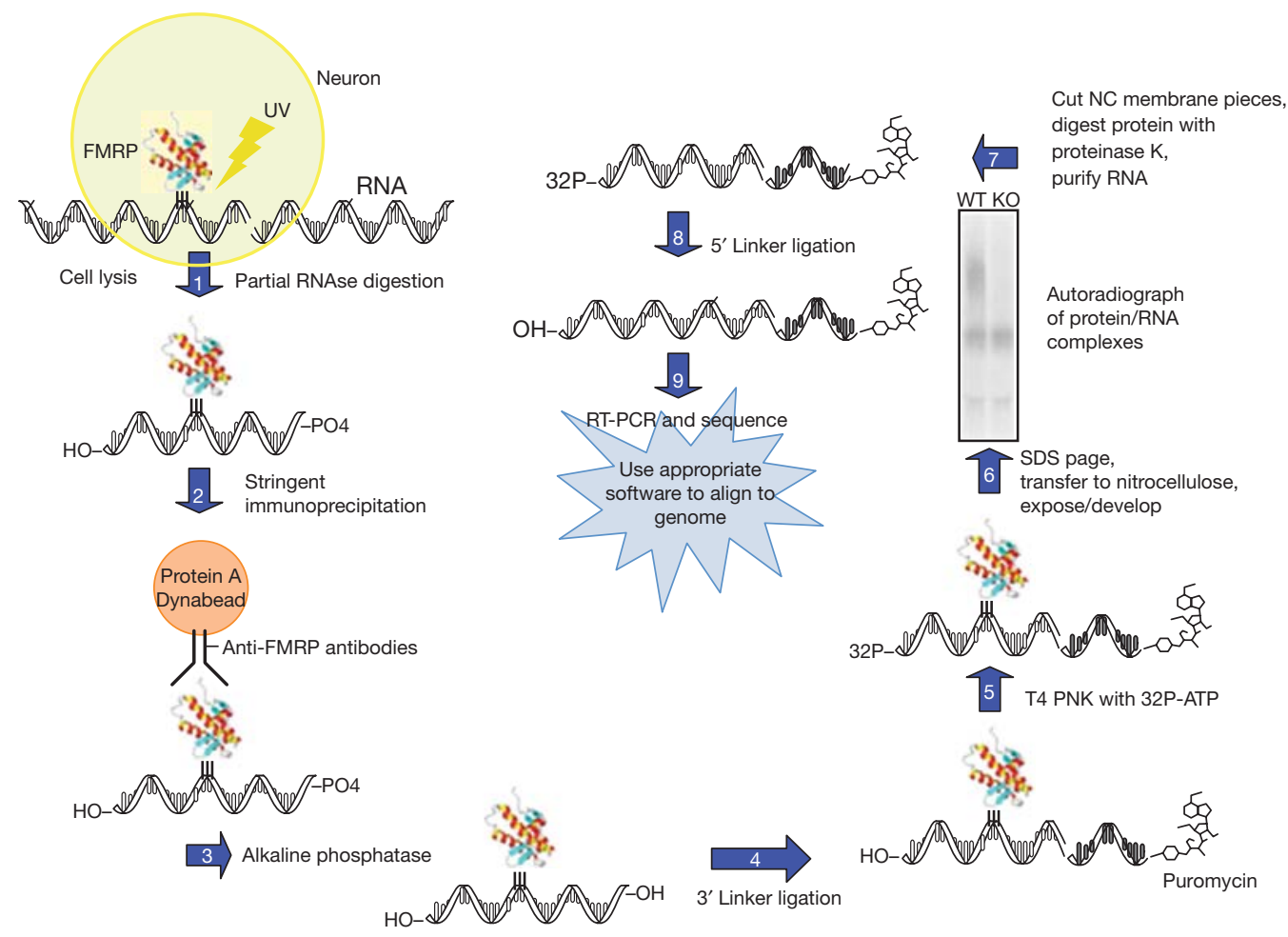

Figure 1. Basic scheme of the HITS-CLIP method. Beginning at the upper left and moving counterclockwise, tissue (e.g., brain) or cells is UV irradiated at $254 \mathrm{~nm}$ introducing covalent cross-links between RNA-protein complexes in living cells. 1. Cell lysis and partial RNase digestion reduces the modal size of cross-linked RNA "tags" to a size determined by the experimenter; 50-100 nucleotides is ideal. RNase A and T1 leave a 5'-OH and a $3^{\prime}$ phosphate group on the digested RNA. 2. Cross-linking allows stringent immunoprecipitation of RNAbinding protein:RNA complexes. 3 and 4 . The $3^{\prime}$ phosphate is removed by alkaline phosphatase, to prevent intramolecular RNA circularization during the ligation of a linker to the $3^{\prime}$ end of the RNA tags in step 4 . This linker is blocked at the $3^{\prime}$ end with a puromycin molecule to prevent competing linker-linker ligation reactions. 5. The RNA tags are then labeled at the $5^{\prime}$ end with $\mathrm{T} 4$ polynucleotide kinase and ${ }^{32} \mathrm{P}-\gamma$ ATP. 6. RNABP:RNA complexes are released from beads, run on denaturing SDS-PAGE, transferred to nitrocellulose, and imaged by autoradiography. SDS-PAGE and transfer to nitrocellulose are two important additional purification steps to separate the desired RNABP:RNA complexes away from other RNABPs or free RNA. 7. The radioactive RNABP:RNA complex is excised from the nitrocellulose filter, digested with proteinase $\mathrm{K}$ to remove the RNABP and to elute the RNA, which is then isolated by phenol-chloroform extraction and ethanol precipitation. 8. A second linker is added to the $5^{\prime}$ end of the RNA. 9. The RNA is amplified by RT-PCR and sequenced by high-throughput sequencing methods. The sequences of the tags can then be aligned with the genome of interest to produce a genome-wide map of where the RNABP was bound to RNA in vivo.

motifs (Fig. 2, the placement of the ribosomes on the mRNA is for illustrative purposes only and is not meant to convey a particular congregation at the $3^{\prime}$ end). These seemly paradoxical observations lead one to ask how does FMRP associate with polysomes yet still repress translation, and how does FMRP bind certain mRNAs in an apparently cis element-independent man- ner? Finally, do the CLIP results give insight into the fragile $\mathrm{X}$ syndrome or autism spectrum disorders (ASDs)?

The observation that FMRP represses translation (Laggerbauer et al. 2001; Li et al. 2001) but does so while associating with polysomes (Khandjian et al. 1996, 2004; Corbin et al. 1997; Feng et al. 1997a,b; Stefani et al. 2004) has 


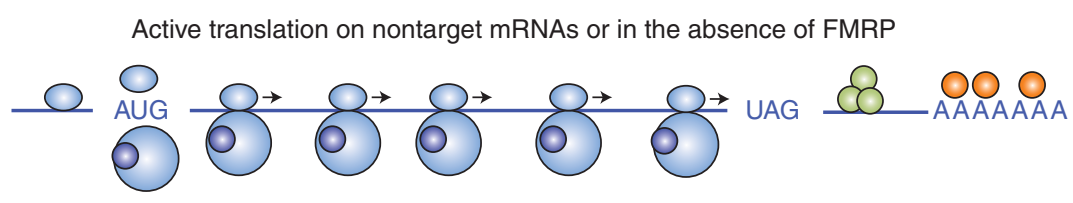

Repressed translation on target mRNAs in the presence of FMRP

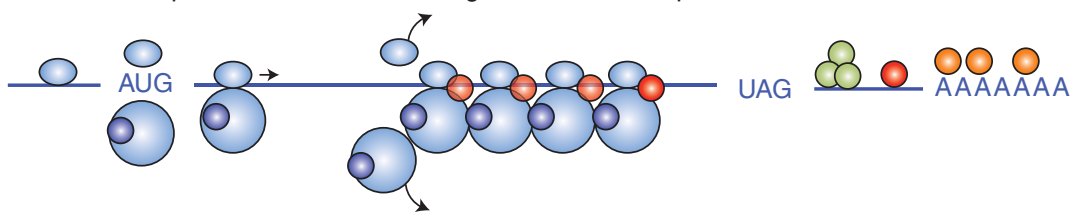

Figure 2. FMRP stalls ribosomes during elongation to repress protein synthesis. (Upper panel) Active translation: In the absence of FMRP, brain transcripts are shown being translated into protein by translocating ribosomes (made up of $40 \mathrm{~S}$ and $60 \mathrm{~S}$ subunits shown in light blue), which assemble at the start codon (i.e., AUG, initiation) and dissociate at the stop codon (i.e., UAG, termination). Ribosomal protein $\mathrm{P} 0$ is shown as a darker blue sphere on the $60 \mathrm{~S}$ subunits. The poly(A)-binding protein (PABP) and the Hu family of RNABPs interacting with specific binding sites in $3^{\prime}$ UTRs are depicted with orange and green spheres, respectively. All four of these RNAbinding proteins are polyribosome associated, each by a different mechanism, and for this reason PABP, Hu, and P0 are shown as contrast for the properties and function of FMRP. (Lower panel) Repressed translation is associated with FMRP interaction with target mRNAs. FMRP preferentially interacts with specific mRNAs and in this context inhibits protein synthesis by stalling ribosomal translocation on those transcripts as part of a micrococcal nuclease-resistant multiribosome complex. This inhibition appears to be reversible, as it can be acutely relieved by competing FMRP off of polyribosomes with an RNA decoy; it is unknown whether this might occur in vivo owing to changes in the phosphorylation state of FMRP, its degradation by the proteasome, interactions with other proteins, noncoding RNAs, or other physiologic effectors. The stoichiometry of FMRP and stalled ribosomes remains to be determined. We have drawn a minimum of one (red) FMRP present in the stalled complex, recognizing the possibility that additional FMRP molecules (illustrated by transparent red figures) may be present. The presence of some FMRP in the UTRs (depicted on the $3^{\prime}$ UTR) is consistent with FMRP HITS-CLIP results. (From Darnell et al. 2011; reprinted with modifications, with permission, from Elsevier (C) 2011.)

given rise to the idea that it inhibits polypeptide elongation (ribosome transit) (Ceman et al. 2003) but much of the initial data supporting that idea was based on overexpression of FMRP, cultured cells, and the use of copy DNA (cDNA) reporter constructs. The identification and validation of a robust set of in vivo mRNA targets of FMRP, and an equally high-confidence set of nontarget mRNAs as controls, allowed evaluation of this hypothesis in a physiologically relevant setting (Darnell et al. 2011). Darnell et al. devised an in vitro assay of translation using the same starting material used to measure FMRP mRNA binding (a polyribosomal extract from mouse brain) so that mRNA binding could be correlated with function with statistical significance. They found that FMRP target mRNAs were associated with stalled ribosomes that were resistant to runoff, whereas mRNAs that were not bound to FMRP (as assessed by HITSCLIP) showed a typical run-off profile and shifted from the polysome region to lighter fractions of the sucrose gradient. Although the mechanism by which FMRP stalls ribosomes remains to be determined, it seems clear that this is the primary mechanism by which FMRP inhibits translation (illustrated in Fig. 2).

Presumably related to ribosome stalling is the fact that FMRP interacts with coding sequences. Does FMRP act as a "roadblock" for transiting 
ribosomes as has been suggested for ashlp mRNA in yeast (Chartrand et al. 2002)? Does it act in a manner analogous to SRP, which causes reversible ribosome stalling on mRNAs encoding secreted or membrane-associated proteins (Wolin and Walter 1988)? Perhaps FMRP blocks peptide elongation through interactions with eukaryotic elongation factor 2 (eEF2) (Sutton et al. 2007; Park et al. 2008). Much remains to be determined about FMRP's mechanism of action and whether its apparently reversible action to repress translation is mediated by its phosphorylation state (Ceman et al. 2003), turnover (Hou et al. 2006), or another mechanism.

Finally, the set of mRNA substrates to which FMRP cross-links begins to offer some insight into the etiology of the fragile $\mathrm{X}$ syndrome specifically, and ASDs more generally. For example, of the 842 FMRP target mRNAs, 28 have also been linked to ASDs including neuroligin 3, neurexin 1, shank3, PTEN, TSC2, and neurofibromatosis 1 , suggesting that alterations in the functional levels of these proteins in neurons may underlie the common symptoms in fragile $\mathrm{X}$ syndrome and autism (Darnell et al. 2011). Other FMRP target mRNAs whose encoded proteins are implicated in ASDs include those involved in the ERK and mTOR pathways, NMDA receptor complexes, regulators of small GTPases, and cell-cell adhesion molecules (Kelleher and Bear 2008; Hoeffer and Klann 2010). The FMRP CLIP data have revealed other potential insights into FMRP function. Consider that about onethird of the FMRP CLIP targets encode presynaptic proteins (Darnell et al. 2011). Indeed, a presynaptic function for FMRP has been suggested by localization studies that have found FMRP in axons and growth cones (Feng et al. 1997b; Antar et al. 2006; Christie et al. 2009) as well as the characterization of axonal growth cone motility (Antar et al. 2006; Li et al. 2009), elongation (Tessier and Broadie 2008), and pathfinding (Michel et al. 2004) defects in both fly and mouse models of fragile $\mathrm{X}$ syndrome. In addition, there is experimental support for a presynaptic role in synapse formation and the establishment of circuitry (Zhang et al. 2001b; Hanson and Madison 2007; Bureau et al. 2008; Gibson et al. 2008). Recent studies on the role of the Aplysia FMRP homolog (ApFMRP) in sensory to motor neuron synaptic plasticity supports both a pre- and postsynaptic role for FMRP in regulating protein synthesis in response to synaptic stimulation (Till et al. 2011). A fruitful area for further research is to connect these observations with the set of presynaptic mRNAs whose translation is regulated by FMRP (Darnell et al. 2011).

\section{CPEB}

The cytoplasmic polyadenylation elementbinding protein CPEB is an mRNA-specific translational control factor that was initially identified for its role in regulating cytoplasmic polyadenylation during Xenopus oocyte maturation (reviewed in Mendez and Richter 2001). CPEB has two RNA-recognition domains (RRM motifs) and two zinc-finger motifs (Hake and Richter 1994; Hake et al. 1998), and by binding to the $3^{\prime}$ UTR cytoplasmic polyadenylation element $(\mathrm{CPE})$ found in specific mRNAs, it recruits a number of interacting proteins to modulate poly(A) tail length and as a result, translation (Richter 2007). CPEB activity begins in the nucleus, where it binds the CPE of premRNAs, which like most nuclear pre-mRNAs, probably have long poly(A) tails (Lin et al. 2010). Following export to the cytoplasm, CPEB associates with a number of factors including Gld-2, a noncanonical poly(A) polymerase, and PARN, a poly(A) ribonuclease. PARN is the more active of the enzymes and thus shortens the poly(A) tail to usually $\sim 20-40$ nucleotides. Hormonal stimulation leads to CPEB phosphorylation, which expels PARN from the RNP complex; as a consequence, the poly $(\mathrm{A})$ tail is elongated by Gld2 (Barnard et al. 2004; Kim and Richter 2006, 2007). The poly(A) tail is then bound by poly(A)-binding protein (PABP), which in turn, helps recruit the initiation complex to the $5^{\prime}$ end of the mRNA. Indeed in a general sense, genome-wide analysis has shown that poly(A) tail length is positively correlated with both the ribosome density on a transcript and the degree of association of PABP, providing additional support for the model that poly(A) tail length regulates translation through $\mathrm{PABP}$ 
and the initiation complex, primarily eIF4G (Halbeisen et al. 2008).

CPEB also represses translation by recruiting specific eIF4E-binding proteins (4E-BPs, neuroguidin in neurons, maskin in oocytes) to the mRNA (Stebbins-Boaz et al. 1999; Richter and Sonenberg 2005; Jung et al. 2006). 4E-BPs repress translation by binding eIF4E, the capbinding protein, which prevents eIF4E from associating with eIF4G and thus inhibits initiation. Neuroguidin localizes to puncta in dendrites and growth cones, and is frequently seen at the very tip of filopodia and at the leading edges of growth cones. Knockdown of the neuroguidin homolog in Xenopus causes a failure of neural tube closure and inhibition of neural crest cell migration, suggesting an important role for CPEB- and neuroguidin-mediated translational repression in neurons during development (Jung et al. 2006).

Vertebrates contain four CPEB paralogs; CPEB1 described above may be functionally distinct from CPEB proteins 2-4. Inhibition of CPEB1 activity, through expression of dominant-negative forms of the protein or in Cpebl knockout (KO) mice, leads to defects in learning, memory, synaptic plasticity, dendritic arborization, and neuronal circuit formation (Alarcon et al. 2004; Berger-Sweeney et al. 2006; McEvoy et al. 2007; Bestman and Cline 2008). CPEB1 inhibits translation of its target mRNAs until glutamatergic activation (Wells et al. 2001) stimulates its phosphorylation by either Aurora kinase A (Mendez et al. 2000a,b; Huang et al. 2002) or Camk2a (Atkins et al. 2004, 2005), resulting in increased mRNA polyadenylation and translation at synapses. The strongest evidence for participation of CPEB1 in local translation is its localization to postsynaptic sites in dendrites $(\mathrm{Wu}$ et al. 1998) and enrichment of phospho-CPEB1 in a postsynaptic density (PSD) fraction purified from rat neurons (Atkins et al. 2004), although it is not entirely clear that the antibodies used did not cross-react with either the CPEB2-4s or other phosphoproteins because a Cpeb1 $\mathrm{KO}$ was not available as a negative control at that time.

Recently it was suggested that CPEB1 may also regulate local translation in hippocampal growth cones in response to neurotrophin stim- ulation through regulation of CPE sites in $\beta$ catenin mRNA (Ctnnb1) (Kundel et al. 2009). This raises an interesting issue in the context of a related study by Holt and colleagues, also addressing whether CPEB regulates local translation in the growth cone (Lin et al. 2009). In the latter study both the CPE and cytoplasmic polyadenylation of mRNAs were required for translation-dependent chemotropic responses, but CPEB1 itself was not. Because other RNA-binding proteins can potentially bind the $\mathrm{CPE}$ and regulate cytoplasmic polyadenylation (Slevin et al. 2007), studies using overexpression of the CPEB RNA-binding domain (RBD) to inhibit CPEB activity may also block CPE binding by other RNABPs. The CPE, with a consensus of $\mathrm{U}_{4-6} \mathrm{AUU}$, is similar to other U-rich or UA-rich binding sites for the large family of ARE-binding proteins, including $\mathrm{Hu}$ (discussed below), and, in fact, the Xenopus homolog of Hu, ElrA, has been reported to bind the CPE (Slevin et al. 2007). The extent to which mammalian neuronal $\mathrm{Hu}$ isoforms may interact with CPEB1 to control translation is an interesting question for further study.

In sum, although it is likely that CPEB1 fulfills an important role in regulating neuronal translation it is not fully established that CPEB1 is responsible for local translational control underlying long-term synaptic plasticity changes. CPEB2-4 are also expressed in neurons and there is significant data from Aplysia and fly homologs to suggest that they may also regulate local translation. CPEB2-4 differ from CPEB1 in that they do not bind the CPE and do not regulate polyadenylation but instead recognize a different RNA consensus sequence (Huang et al. 2006). They also lack the Aurora kinase A phosphorylation site of CPEB1 (Theis et al. 2003). They have been shown to regulate translation in an $N$-methyl-D-aspartate receptor (NMDAR) -dependent manner in neurons, through a mechanism independent of $\mathrm{CPE}$ binding and polyadenylation (Huang et al. 2006).

The Aplysia CPEB homolog, ApCPEB, is neuron specific and most similar to $\mathrm{CPEB} 3$ (Liu and Schwartz 2003; Si et al. 2003a; Theis et al. 2003). Like CPEB3 and 4 in mouse, ApCPEB is induced in response to synaptic 
activation (Theis et al. 2003) and is required for long-term facilitation at the activated synapse, strengthening the model that "type 2" neuronal CPEBs regulate protein synthesis-dependent forms of long-term synaptic plasticity. Owing to an amino-terminal glutamine-rich domain, ApCPEB has the additional property of forming prionlike particles that may be related to synaptic changes underlying long-term memory storage or form a synaptic "tag" marking that synapse (Darnell 2003; Si et al. 2003b, 2010).

Notably, loss of function of the fly homolog of CPEB1 (Orb) has phenotypes in the fly oocyte (Lantz et al. 1994) but has not been linked to a neuronal defect. However, the CPEB2 -4 homo$\log$, Orb2, expressed predominantly in neurons and also containing a prionlike domain, is necessary for some forms of long-term memory (LTM). Intriguingly, its effects on LTM are dependent on the prionlike domain (Keleman et al. 2007). Taken together, results from Aplysia and flies suggest that elucidation of the mRNA targets and functions of CPEB2-4 in addition to CPEB1 will clarify mechanisms underlying some forms of LTM.

\section{PUMILIO}

The regulation of cytoplasmic polyadenylation is an important point of translational control for another family of RNABPs, the pumilio (pum) or PUF family (Wickens et al. 2002; Quenault et al. 2011). PUF proteins harbor a conserved Pumilio homology domain that binds RNA, and the proteins regulate cytoplasmic poly(A) length and may compete or cooperate with CPEB1. Like CPEB1, Pumilio regulates gene expression through two mechanisms, in this case by (1) affecting the stability of target mRNAs through recruitment of a deadenylase complex to shorten poly(A) tails and promote mRNA turnover (reviewed in Quenault et al. 2011) and (2) repressing translation directly. A carboxy-terminal RBD in Pumilio, first described by Zamore and colleagues (1997), recognizes the $16 \mathrm{nt}$ "nanos response element" (NRE) in the $3^{\prime}$ UTR of hunchback mRNA in fly embryos (Wharton and Struhl 1991). Pumilio recruits two other proteins: Nanos, which is also involved in RNA localization, and Brat, which binds the eIF4E-like cap-binding protein d4EHP (Cho et al. 2006). Unlike eIF4E, d4EHP does not interact with deIF4G; consequently initiation does not occur because without eIF4G, the 40S ribosomal subunit is not recruited to the mRNA (Cho et al. 2006). Pumilio also has been shown to have cap-binding activity itself and so may compete with eIF4E to block initiation (Cao et al. 2010). Pumilio activates translation in some cases through cooperative binding with CPEB1 on transcripts containing both NRE and CPE elements, and may stabilize CPEB binding, but translational activation does not appear to involve altered polyadenylation of target mRNAs (Pique et al. 2008). Pumilio has been found to associate with a Nanos homolog and CPEB in Xenopus (Nakahata et al. 2001), supporting the conservation of this mechanism.

There are two human homologs, Pum1 and 2 , present in the brain. To date, neither has been linked to a human cognitive disease, and there are no reports of neuronal defects in $\mathrm{KO}$ mice to date. Nonetheless, compelling evidence exists for an important role in mammalian neuronal function (reviewed in Baines 2005). Loss of Pumilio leads to defective LTM in flies (Dubnau et al. 2003), likely owing to its effects on dendrite morphogenesis as well as synapse growth and function (Mee et al. 2004; Menon et al. 2004; Ye et al. 2004). Pum 2 is present in RNPs in the cell body and dendrites of rodent hippocampal neurons (Vessey et al. 2006). Studies using bidirectional manipulation of Pum2 levels show reciprocal changes in dendrite outgrowth, the density and morphology of dendritic spines, and the frequency of miniature excitatory postsynaptic currents (mEPSCs) (Vessey et al. 2010), revealing that Pum2 negatively regulates all three phenotypes. The observed increased mEPSC frequency appears to be owing to an increased number of excitatory synapses on dendritic shafts in the absence of Pum2 (Vessey et al. 2010).

\section{Zip Code Binding Protein}

Zip code binding protein 1 (ZBP1) is an interesting example of a neuronal RNA-binding protein recognized for its role in mRNA localization 
that also represses translation. ZBP1 harbors 4 KH-type RBDs. The homologs of chicken ZBP1 (mammalian IMP1-3 or IGF2BP1-3) are oncofetal proteins that are highly expressed during development, absent postnatally, and are reexpressed in a high percentage of tumors (Tessier et al. 2004). Nonetheless, ZBP1 appears to have an important role in developing neurons. It is present in granules in the somatodendritic compartment together with $\beta$-actin mRNA, actb, through interactions with a 54-nucleotide binding site (the "zip code") in the $3^{\prime}$ UTR (Zhang et al. 2001a). These granules contain components of the exon junction complex, indicating that they are translationally repressed on exiting the nucleus (Jonson et al. 2007). In primary neurons, the levels of ZBP1 in growth cones (Zhang et al. 2001a), dendrites, and spines (Tiruchinapalli et al. 2003) is positively correlated with neuronal activity. Significantly, knockdown of ZBP1 in cultured neurons eliminates a BDNF-stimulated increase in actin-rich dendritic spines (Eom et al. 2003). Knockdown or overexpression of ZBP1 in cultured neurons was found to decrease complexity of the dendritic arbor and this was dependent on the ZBP1 RBDs (Perycz et al. 2011). No effect was found on established arbors, suggesting an important role for ZBP1 during the critical period of dendritogenesis (Perycz et al. 2011).

Direct translational control by ZBP1 in neurons was shown by Huttelmaier and colleagues who found that ZBP1 repressed initiation on neuronal actb mRNA by binding to the $3^{\prime}$ UTR zip-code sequence and interfering with $80 \mathrm{~S}$ complex formation (Huttelmaier et al. 2005). Mechanistic studies revealed that phosphorylation of ZBP1 by Src kinase on Y396 decreased binding to the zip code and allowed initiation, resulting in local synthesis of $\beta$-actin (Huttelmaier et al. 2005). This mechanism was also reported to regulate local translation of actb in growth cones to allow turning in response to brain-dervived neurotrophic factor (BDNF) (Sasaki et al. 2010). Furthermore, nonphosphorylatable Y396F-ZBP1 was unable to rescue the ZBP1 knockdown effect on dendritic arborization (Perycz et al. 2011). ZBP1 has also been reported to increase internal ribosome entry site
(IRES) -dependent initiation of the hepatitis $\mathrm{C}$ virus RNA by interacting with both $5^{\prime}$ and $3^{\prime}$ UTRs (Weinlich et al. 2009); however, a function to regulate IRES-dependent initiation in neurons has not been established.

\section{CAPRIN}

Caprins1 and 2 (also known as RNG105 and RNG140) are among the newest additions to the list of potential translational regulators in neurons. Caprins bind RNA through an amino-terminal coiled-coil motif and a carboxy-terminal RGG box. Caprin1 (Grill et al. 2004) associates with polyribosomes in rat cortex (Angenstein et al. 2005) and is a component of the same ribosome-containing granules as the fragile $\mathrm{X}$ mental retardation autosomal homolog proteins FXRPs (Shiina et al. 2005; Shiina and Tokunaga 2010), suggesting a role in translational regulation similar to that of the FMRP family. Knockdown of caprin1 or caprin2 in cultured mouse neurons causes a reduction in the number, length, and branching of dendrites (Shiina and Tokunaga 2010) and studies on primary neuronal cultures from caprin1 $\mathrm{KO}$ mice show defects in synapse development (Shiina et al. 2010). BDNF treatment caused the dissociation of caprin 1 and its mRNA targets from these granules into polyribosomes, suggesting that neural activity relieves translational repression imposed by caprin 1 (Shiina et al. 2005). Caprin 1 and caprin2 localize to different granules in dendrites and so appear to have distinct functions in neurons, although both appear to be involved in dendrite and spine development.

The caprins nonspecifically repress translation in in vitro translation systems and globally repress translation when overexpressed in vivo. These findings might suggest that the caprins repress translation nonspecifically. However, loss of function of caprin does not increase global translation rates, raising a more general issue regarding overexpression of RNABPs in functional assays, which has been addressed in the context of caprin-induced stress granule (SG) formation (Solomon et al. 2007). SGs are the result of clustering of mRNAs, stalled preinitiation complexes, and RNABPs caused by 
phosphorylation of eIF $2 \alpha$ or inhibition of the eIF4F complex (see Decker and Parker 2012). Caprins belong to a group of mRNA-binding proteins (including FMRP) that nucleate SGs when expressed at greater than physiological levels. Solomon et al. (2007) found that caprin overexpression caused eIF $2 \alpha$ phosphorylation resulting in both global translational repression and the formation of SGs. Although it is possible that this might be related to the physiologic role of caprins, it raises a red flag concerning the assignment of the role of translational repressor based solely on overexpression studies.

\section{HU}

The mammalian neuronal homologs of the Drosophila ELAV protein ( $\mathrm{Hu} \mathrm{B}, \mathrm{C}$, and D) have been reported to regulate mRNA stability (Bolognani and Perrone-Bizzozero 2008), translation (Fukao et al. 2009), and pre-mRNA splicing (Zhu et al. 2006) to regulate nervous system development and function (Okano and Darnell 1997; Akamatsu et al. 1999; reviewed by Antic and Keene 1997; Hinman and Lou 2008). ELAV is known to be essential for nervous system development and function in flies (Campos et al. 1985; Robinow et al. 1988). The mammalian homologs were first cloned as antigens of paraneoplastic antibodies in the human neurologic $\mathrm{Hu}$ syndrome (Szabo et al. 1991; Posner and Dalmau 1997) and studies using mice in which these proteins have been knocked out or overexpressed show a number of neuronal, learning, and memory phenotypes (Akamatsu et al. 2005; Bolognani et al. 2006, 2007a,b; Tanner et al. 2008). Hu has been consistently shown to be up-regulated in hippocampal neurons after contextual (Bolognani et al. 2004) or spatial learning tasks (Quattrone et al. 2001; Pascale et al. 2004) and after glutamate receptor activation (Tiruchinapalli et al. 2008). The roles of the neuronal Hu proteins in development, plasticity, and memory have been recently reviewed (Deschenes-Furry et al. 2006; Pascale et al. 2008).

Hu proteins have three RRM domains and bind to AU- and GU-rich elements in the $3^{\prime}$ UTRs of specific mRNA transcripts. These ele- ments, also known as AREs, are also binding sites for a number of RNABPs that promote turnover of these mRNAs, including KSRP, TTP, AUF1, and BRF1. Hu is thought to bind the same or similar elements to protect ARE-containing transcripts from degradation. As a group, the ARE-binding proteins regulate mRNA stability in response to cell stimulation including stress, proliferative stimulation, immune signaling, and developmental signals.

$\mathrm{Hu}$ can directly regulate the translation of target mRNAs as well. Neuronal Hu's are localized to somatic and dendritic granules containing ribosomes (Bolognani et al. 2004) and are polyribosome-associated in human medulloblastoma cells (Gao and Keene 1996), PC12 cells (Fukao et al. 2009), primary neurons (Tiruchinapalli et al. 2008), and brain (Bolognani et al. 2004; Darnell et al. 2009). Polyribosome-associated $\mathrm{Hu}$ levels increase after $\mathrm{KCl}$ stimulation (Tiruchinapalli et al. 2008) or learning (Bolognani et al. 2004), suggesting that $\mathrm{Hu}$ increases translation of its mRNA targets in response to neuronal activity by promoting initiation (Chen and Shyu 2009; Fukao et al. 2009) supported by the increased association of its mRNA targets with polyribosomes (Antic et al. 1999; MazanMamczarz et al. 2003; Kawai et al. 2006; Galban et al. 2008). Stimulation of translation by $\mathrm{HuD}$ has been shown to be dependent on both the poly-A tail and $5^{\prime}$ cap and occurs through direct interaction of $\mathrm{HuD}$ with the helicase eIF4A (Fukao et al. 2009). This mechanism of facilitating initiation is critical for $\mathrm{Hu}$-dependent neurite outgrowth in PC12 cells (Fukao et al. 2009). Hu has also been proposed to inhibit translation in some cases (reviewed in Hinman and Lou 2008).

\section{CONCERTED FUNCTION OF TRANSLATIONAL REGULATORY PROTEINS IN NEURONS}

In sum, intriguing evidence supports the idea that specific mRNA-binding proteins regulate translation that in turn mediates neuronal function including synaptic plasticity. Moreover, mounting evidence suggests that such regulation is likely to require the concerted action of 
the translational regulators discussed in this review. Although identification of important neuronal translational regulatory proteins through genetic and biochemical approaches has been quite successful, identification of the mRNAs whose expression is controlled by these binding proteins remains a major hurdle limiting our understanding of the mechanisms involved. Application of HITS-CLIP and related techniques to FMRP, CPEB, Pumilio, ZBP, caprin, and $\mathrm{Hu}$ in brain, and their use in quantifying changes in RNA binding in response to activity, or in subcellular fractions such as polyribosomes or purifiable granules, or during development will likely lead to dramatic advances in our understanding of how these proteins fine tune the synthesis of key neuronal proteins.

\section{RELEVANCE TO THERAPY FOR HUMAN COGNITIVE AND BEHAVIORAL DISEASES}

One approach to modulating translation in neurons to ameliorate symptoms of diseases such as fragile X syndrome or some cases of autism, both thought to be caused by "runaway translation," is to target the general signaling pathways that transduce engagement of cell-surface receptors to increased translation, including PI3K/Akt/mTOR and MEK/ERK (Kelleher and Bear 2008; Hoeffer and Klann 2010). These pathways are already the subject of anticancer therapy research because the cell cycle uses similar pathways to transduce growth factor signals into translational output as do neurons (Guertin and Sabatini 2005; Tee and Blenis 2005; Sabatini 2006; Frost et al. 2009; Dowling et al. 2010; Livingstone et al. 2010; Silvera et al. 2010). Hopefully, very specific therapies may result from understanding binding sites and mechanism of translational control at the molecular level, both of which can be addressed through HITS-CLIP "mapping” of physiologic RNAbinding protein:RNA interactions paired with appropriately designed mechanistic studies using endogenous mRNA targets. The majority of the mRNA translational regulatory proteins are thought to repress translation whether at the level of elongation, like FMRP, or initiation, like CPEB, pumilio, and ZBP. Replacement of the repression lost in disease might be achieved by delivery of a mimic of FMRP activity to stall ribosomes, for example. Furthermore, it's possible that generally slowing translation with the off-target use of antibiotics might take the edge off of excessive translation and provide therapeutic benefit, as has been suggested for fragile X syndrome (Darnell et al. 2011).

\section{REFERENCES}

* Reference is also in this collection.

Akamatsu W, Okano HJ, Osumi N, Inoue T, Nakamura S, Sakakibara S, Miura M, Matsuo N, Darnell RB, Okano H, et al. 1999. Mammalian ELAV-like neuronal RNA-binding proteins $\mathrm{HuB}$ and $\mathrm{HuC}$ promote neuronal development in both the central and the peripheral nervous systems. Proc Natl Acad Sci 96: 9885-9890.

Akamatsu W, Fujihara H, Mitsuhashi T, Yano M, Shibata S, Hayakawa Y, Okano HJ, Sakakibara S, Takano H, Takano T, et al. 2005. The RNA-binding protein $\mathrm{HuD}$ regulates neuronal cell identity and maturation. Proc Natl Acad Sci 102: 4625-4630.

Alarcon JM, Hodgman R, Theis M, Huang YS, Kandel ER, Richter JD. 2004. Selective modulation of some forms of Schaffer collateral-CA1 synaptic plasticity in mice with a disruption of the CPEB-1 gene. Learn Mem 11: 318-327.

Angenstein F, Evans AM, Ling SC, Settlage RE, Ficarro S, Carrero-Martinez FA, Shabanowitz J, Hunt DF, Greenough WT. 2005. Proteomic characterization of messenger ribonucleoprotein complexes bound to nontranslated or translated poly $(\mathrm{A}) \mathrm{mRNAs}$ in the rat cerebral cortex. J Biol Chem 280: 6496-6503.

Antar LN, Li C, Zhang H, Carroll RC, Bassell GJ. 2006. Local functions for FMRP in axon growth cone motility and activity-dependent regulation of filopodia and spine synapses. Mol Cell Neurosci 32: 37-48.

Antic D, Keene JD. 1997. Embryonic lethal abnormal visual RNA-binding proteins involved in growth, differentiation, and posttranscriptional gene expression. Am J Hum Genet 61: 273-278.

Antic D, Lu N, Keene JD. 1999. ELAV tumor antigen, Hel$\mathrm{N} 1$, increases translation of neurofilament M mRNA and induces formation of neurites in human teratocarcinoma cells. Genes Dev 13: 449-461.

Atkins CM, Nozaki N, Shigeri Y, Soderling TR. 2004. Cytoplasmic polyadenylation element binding protein-dependent protein synthesis is regulated by calcium/calmodulin-dependent protein kinase II. J Neurosci 24: 5193-5201.

Atkins CM, Davare MA, Oh MC, Derkach V, Soderling TR. 2005. Bidirectional regulation of cytoplasmic polyadenylation element-binding protein phosphorylation by $\mathrm{Ca}_{2}^{+} /$calmodulin-dependent protein kinase II and protein phosphatase 1 during hippocampal long-term potentiation. J Neurosci 25: 5604-5610.

Baines RA. 2005. Neuronal homeostasis through translational control. Mol Neurobiol 32: 113-121. 
J.C. Darnell and J.D. Richter

Barnard DC, Ryan K, Manley JL, Richter JD. 2004. Symplekin and xGLD-2 are required for CPEB-mediated cytoplasmic polyadenylation. Cell 119: 641-651.

Berger-Sweeney J, Zearfoss NR, Richter JD. 2006. Reduced extinction of hippocampal-dependent memories in CPEB knockout mice. Learn Mem 13: 4-7.

Bestman JE, Cline HT. 2008. The RNA binding protein $\mathrm{CPEB}$ regulates dendrite morphogenesis and neuronal circuit assembly in vivo. Proc Natl Acad Sci 105: 2049420499.

Bolognani F, Perrone-Bizzozero NI. 2008. RNA-protein interactions and control of mRNA stability in neurons. J Neurosci Res 86: 481-489.

Bolognani F, Merhege MA, Twiss J, Perrone-Bizzozero NI. 2004. Dendritic localization of the RNA-binding protein $\mathrm{HuD}$ in hippocampal neurons: Association with polysomes and upregulation during contextual learning. Neurosci Lett 371: 152-157.

Bolognani F, Tanner DC, Merhege M, Deschenes-Furry J, Jasmin B, Perrone-Bizzozero NI, et al. 2006. In vivo posttranscriptional regulation of GAP-43 mRNA by overexpression of the RNA-binding protein HuD. J Neurochem 96: $790-801$.

Bolognani F, Qiu S, Tanner DC, Paik J, Perrone-Bizzozero NI, Weeber EJ, et al. 2007a. Associative and spatial learning and memory deficits in transgenic mice overexpressing the RNA-binding protein HuD. Neurobiol Learn Mem 87: 635-643.

Bolognani F, Tanner DC, Nixon S, Okano HJ, Okano H, Perrone-Bizzozero NI, et al. 2007b. Coordinated expression of $\mathrm{HuD}$ and GAP-43 in hippocampal dentate granule cells during developmental and adult plasticity. $\mathrm{Neu}$ rochem Res 32: 2142-2151.

Brown V, Jin P, Ceman S, Darnell JC, O'Donnell WT, Tenenbaum SA, Jin X, Feng Y, Wilkinson KD, Keene JD, et al. 2001. Microarray identification of FMRP-associated brain mRNAs and altered mRNA translational profiles in Fragile X Syndrome. Cell 107: 477-487.

Bureau I, Shepherd GM, Svoboda K. 2008. Circuit and plasticity defects in the developing somatosensory cortex of FMR1 knock-out mice. J Neurosci 28: 5178-5188.

Campos AR, Grossman D, White K. 1985. Mutant alleles at the locus elav in Drosophila melonagaster lead to nervous system defects. A developmental-genetic analysis. J Neurogenet 2: 197-218.

Cao Q, Padmanabhan K, Richter JD. 2010. Pumilio 2 controls translation by competing with eIF4E for 7-methyl guanosine cap recognition. RNA 16: 221-227.

Ceman S, O’Donnell WT, Reed M, Patton S, Pohl J, Warren ST. 2003. Phosphorylation influences the translation state of FMRP-associated polyribosomes. Hum Mol Genet 12: 3295-3305.

Chartrand P, Meng XH, Huttelmaier S, Donato D, Singer RH. 2002. Asymmetric sorting of ashlp in yeast results from inhibition of translation by localization elements in the mRNA. Mol Cell 10: 1319-1330.

Chen CY, Shyu AB. 2009. HuD stimulates translation via eIF4A. Mol Cell 36: 920-921.

Chi SW, Zang JB, Mele A, Darnell RB. 2009. Argonaute HITS-CLIP decodes microRNA-mRNA interaction maps. Nature 460: 479-486.
Cho PF, Gamberi C, Cho-Park YA, Cho-Park IB, Lasko P, Sonenberg N. 2006. Cap-dependent translational inhibition establishes two opposing morphogen gradients in Drosophila embryos. Curr Biol 16: 2035-2041.

Christie SB, Akins MR, Schwob JE, Fallon JR. 2009. The FXG: A presynaptic fragile X granule expressed in a subset of developing brain circuits. J Neurosci 29: 1514-1524.

Corbin F, Bouillon M, Fortin A, Morin S, Rousseau F, Khandjian EW. 1997. The fragile X mental retardation protein is associated with poly $(\mathrm{A})^{+} \mathrm{mRNA}$ in actively translating polyribosomes. Hum Mol Genet 6: 14651472.

Costa-Mattioli M, Sossin WS, Klann E, Sonenberg N. 2009. Translational control of long-lasting synaptic plasticity and memory. Neuron 61: 10-26.

Darnell RB. 2003. Memory, synaptic translation, and prions? Cell 115: 767-768.

Darnell RB. 2010. HITS-CLIP: Panoramic views of proteinRNA regulation in living cells. RNA 1: 266-286.

Darnell JC, Jensen KB, Jin P, Brown V, Warren ST, Darnell RB. 2001. Fragile X mental retardation protein targets $G$ Quartet mRNAs important for neuronal function. Cell 107: 489-499.

Darnell JC, Warren ST, Darnell RB. 2004. The fragile X mental retardation protein, FMRP, recognizes G-quartets. Ment Retard Dev Disabil Res Rev 10: 49-52.

Darnell JC, Mostovetsky O, Darnell RB. 2005a. FMRP RNA targets: Identification and validation. Genes Brain Behav 4: 341-349.

Darnell JC, Fraser CE, Mostovetsky O, Stefani G, Jones TA, Eddy SR, Darnell RB. 2005b. Kissing complex RNAs mediate interaction between the Fragile-X mental retardation protein $\mathrm{KH} 2$ domain and brain polyribosomes. Genes Dev 19: 903-918.

Darnell JC, Fraser CE, Mostovetsky O, Darnell RB. 2009. Discrimination of common and unique RNA-binding activities among Fragile X mental retardation protein paralogs. Hum Mol Genet 18: 3164-3177.

Darnell JC, Van Driesche SJ, Zhang C, Hung KY, Mele A, Fraser CE, Stone EF, Chen C, Fak JJ, Chi SW, et al. 2011. FMRP stalls ribosomal translocation on mRNAs linked to synaptic function and autism. Cell 146: 247-261.

De Boulle K, Verkerk AJ, Reyniers E, Vits L, Hendrickx J, Van Roy B, Van den Bos F, de Graaff E, Oostra BA, Willems PJ, et al. 1993. A point mutation in the FMR-1 gene associated with fragile X mental retardation. Nat Genet 3: 3135.

* Decker CJ, Parker R. 2012. P bodies and stress granules: Possible roles in the control of translation and mRNA degradation. Cold Spring Harb Perspect Biol doi: 10.1101/ cshperspect.a012286.

Dent EW, Merriam EB, Hu X. 2011. The dynamic cytoskeleton: Backbone of dendritic spine plasticity. Curr Opin Neurobiol 21: 175-181.

Deschenes-Furry J, Perrone-Bizzozero N, Jasmin BJ. 2006. The RNA-binding protein $\mathrm{HuD}$ : A regulator of neuronal differentiation, maintenance and plasticity. Bioessays 28: $822-833$.

Dowling RJ, Topisirovic I, Fonseca BD, Sonenberg N. 2010. Dissecting the role of mTOR: Lessons from mTOR inhibitors. Biochim Biophys Acta 1804: 433-439. 
Doyle M, Kiebler MA. 2011. Mechanisms of dendritic mRNA transport and its role in synaptic tagging. $E M B O$ J 30: 3540-3552.

Dubnau J, Chiang AS, Grady L, Barditch J, Gossweiler S, McNeil J, Smith P, Buldoc F, Scott R, Certa U, et al. 2003. The staufen/pumilio pathway is involved in Drosophila long-term memory. Curr Biol 13: 286-296.

Ellington AD, Szostak JW. 1990. In vitro selection of RNA molecules that bind specific ligands. Nature 346: $818-822$.

Eom T, Antar LN, Singer RH, Bassell GJ. 2003. Localization of a $\beta$-actin messenger ribonucleoprotein complex with zipcode-binding protein modulates the density of dendritic filopodia and filopodial synapses. J Neurosci 23: 10433-10444.

Feng Y, Absher D, Eberhart DE, Brown V, Malter HE, Warren ST. 1997a. FMRP associates with polyribosomes as an mRNP, and the I304N mutation of severe fragile X syndrome abolishes this association. Mol Cell 1: 109-118.

Feng Y, Gutekunst CA, Eberhart DE, Yi H, Warren ST, Hersch SM. 1997b. Fragile X mental retardation protein: Nucleocytoplasmic shuttling and association with somatodendritic ribosomes. J Neurosci 17: 1539-1547.

Flexner LB, Flexner JB. 1968. Intracerebral saline: Effect on memory of trained mice treated with puromycin. Science 159: $330-331$.

Flexner JB, Flexner LB, Stellar E, De Lahabag, Roberts RB. 1962. Inhibition of protein synthesis in brain and learning and memory following puromycin. J Neurochem 9: 595-605.

Frey U, Morris RG. 1997. Synaptic tagging and long-term potentiation. Nature 385: 533-536.

Frost P, Shi Y, Hoang B, Gera J, Lichtenstein A. 2009. Regulation of D-cyclin translation inhibition in myeloma cells treated with mammalian target of rapamycin inhibitors: Rationale for combined treatment with extracellular signal-regulated kinase inhibitors and rapamycin. $\mathrm{Mol} \mathrm{Can-}$ cer Ther 8: 83-93.

Fukao A, Sasano Y, Imataka H, Inoue K, Sakamoto H, Sonenberg N, Thoma C, Fujiwara T. 2009. The ELAV protein HuD stimulates cap-dependent translation in a Poly(A)and eIF4A-dependent manner. Mol Cell 36: 1007-1017.

Galban S, Kuwano Y, Pullmann RJ, Martindale JL, Kim HH, Lal A, Abdelmohsen K, Yang X, Dang Y, Liu JO, et al. 2008. RNA-binding proteins HuR and PTB promote the translation of hypoxia-inducible factor $1 \alpha$. Mol Cell Biol 28: 93-107.

Gao FB, Keene JD. 1996. Hel-N1/Hel-N2 proteins are bound to poly $(\mathrm{A})^{+}$mRNA in granular RNP structures and are implicated in neuronal differentiation. J Cell Sci 109: $579-589$.

Gibson JR, Bartley AF, Hays SA, Huber KM. 2008. Imbalance of neocortical excitation and inhibition and altered UP states reflect network hyperexcitability in the mouse model of fragile X syndrome. J Neurophysiol 100: 26152626.

Granneman S, Kudla G, Petfalski E, Tollervey D. 2009. Identification of protein binding sites on U3 snoRNA and pre-rRNA by UV cross-linking and high-throughput analysis of cDNAs. Proc Natl Acad Sci 106: 9613-9618.
Grill B, Wilson GM, Zhang KX, Wang B, Doyonnas R, Quadroni M, Schrader JW. 2004. Activation/division of lymphocytes results in increased levels of cytoplasmic activation/proliferation-associated protein-1: Prototype of a new family of proteins. J Immunol 172: 2389-2400.

Guertin DA, Sabatini DM. 2005. An expanding role for mTOR in cancer. Trends Mol Med 11: 353-361.

Hafner M, Landthaler M, Burger L, Khorshid M, Hausser J, Berninger P, Rothballer A, Ascano MJ Jr, Jungkamp AC, Munschauer M, et al. 2010. Transcriptome-wide identification of RNA-binding protein and microRNA target sites by PAR-CLIP. Cell 141: 129-141.

Hagerman RJ, Hagerman PJ, eds. 2002. Fragile X syndrome: Diagnosis, treatment, and research. The Johns Hopkins University Press, Baltimore and London.

Hagerman RJ, Berry-Kravis E, Kaufmann WE, Ono MY, Tartaglia N, Lachiewicz A, Kronk R, Delahunty C, Hessl D, Visootsak J, et al. 2009. Advances in the treatment of fragile X syndrome. Pediatrics 123: 378-390.

Hake LE, Richter JD. 1994. CPEB is a specificity factor that mediates cytoplasmic polyadenylation during Xenopus oocyte maturation. Cell 79: 617-627.

Hake LE, Mendez R, Richter JD. 1998. Specificity of RNA binding by CPEB: Requirement for RNA recognition motifs and a novel zinc finger. Mol Cell Biol 18: 685-693.

Halbeisen RE, Galgano A, Scherrer T, Gerber AP. 2008. Posttranscriptional gene regulation: From genome-wide studies to principles. Cell Mol Life Sci 65: 798-813.

Hanson JE, Madison DV. 2007. Presynaptic FMR1 genotype influences the degree of synaptic connectivity in a mosaic mouse model of fragile X syndrome. J Neurosci 27: 40144018.

Hinman MN, Lou H. 2008. Diverse molecular functions of Hu proteins. Cell Mol Life Sci 65: 3168-3181.

Hoeffer CA, Klann E. 2010. mTOR signaling: At the crossroads of plasticity, memory and disease. Trends Neurosci 33: $67-75$.

Holt CE, Bullock SL. 2009. Subcellular mRNA localization in animal cells and why it matters. Science 326: $1212-$ 1216.

Hou L, Antion MD, Hu D, Spencer CM, Paylor R, Klann E. 2006. Dynamic translational and proteasomal regulation of fragile X mental retardation protein controls mGluRdependent long-term depression. Neuron 51: 441-454.

Huang YS, Jung MY, Sarkissian M, Richter JD. 2002. Nmethyl-D-aspartate receptor signaling results in Aurora kinase-catalyzed CPEB phosphorylation and $\alpha$ CaMKII mRNA polyadenylation at synapses. EMBO J 21: 21392148.

Huang YS, Kan MC, Lin CL, Richter JD. 2006. CPEB3 and CPEB4 in neurons: Analysis of RNA-binding specificity and translational control of AMPA receptor GluR2 mRNA. EMBO J 25: 4865-4876.

Huber KM, Kayser MS, Bear MF. 2000. Role for rapid dendritic protein synthesis in hippocampal mGluR-dependent long-term depression. Science 288: 1254-1257.

Huttelmaier S, Zenklusen D, Lederer M, Dictenberg J, Lorenz M, Meng X, Bassell GJ, Condeelis J, Singer RH. 2005. Spatial regulation of $\beta$-actin translation by Src-dependent phosphorylation of ZBP1. Nature 438: 512-515. 
Irvine D, Tuerk C, Gold L. 1991. SELEXION. Systematic evolution of ligands by exponential enrichment with integrated optimization by non-linear analysis. J Mol Biol 222: $739-761$.

Jensen KB, Darnell RB. 2008. CLIP: Crosslinking and immunoprecipitation of in vivo RNA targets of RNA-binding proteins. Methods Mol Biol 488: 85-98.

Jonson L, Vikesaa J, Krogh A, Nielsen LK, Hansen T, Borup R, Johnsen AH, Christiansen J, Nielsen FC. 2007. Molecular composition of IMP1 ribonucleoprotein granules. Mol Cell Proteomics 6: 798-811.

Jung MY, Lorenz L, Richter JD. 2006. Translational control by neuroguidin, a eukaryotic initiation factor $4 \mathrm{E}$ and CPEB binding protein. Mol Cell Biol 26: 4277-4287.

Kandel ER. 2001. The molecular biology of memory storage: A dialogue between genes and synapses. Science 294: 1030-1038.

Kang H, Schuman EM. 1996. A requirement for local protein synthesis in neurotrophin-induced hippocampal synaptic plasticity. Science 273: 1402-1406.

Kawai T, Lal A, Yang X, Galban S, Mazan-Mamczarz K, Gorospe M. 2006. Translational control of cytochrome c by RNA-binding proteins TIA-1 and HuR. Mol Cell Biol 26: 3295-3307.

Keleman K, Kruttner S, Alenius M, Dickson BJ. 2007. Function of the Drosophila CPEB protein Orb2 in long-term courtship memory. Nat Neurosci 10: 1587-1593.

Kelleher R Jr, Bear MF. 2008. The autistic neuron: Troubled translation? Cell 135: 401-406.

Khandjian EW, Corbin F, Woerly S, Rousseau F. 1996. The fragile $\mathrm{X}$ mental retardation protein is associated with ribosomes. Nat Genet 12: 91-93.

Khandjian EW, Huot ME, Tremblay S, Davidovic L, Mazroui R, Bardoni B. 2004. Biochemical evidence for the association of fragile $\mathrm{X}$ mental retardation protein with brain polyribosomal ribonucleoparticles. Proc Natl Acad Sci 101: 13357-13362.

Kim JH, Richter JD. 2006. Opposing polymerase-deadenylase activities regulate cytoplasmic polyadenylation. $\mathrm{Mol}$ Cell 24: 173-183.

Kim JH, Richter JD. 2007. RINGO/cdk1 and CPEB mediate poly(A) tail stabilization and translational regulation by ePAB. Genes Dev 21: 2571-2579.

Konig J, Zarnack K, Rot G, Curk T, Kayikci M, Zupan B, Turner DJ, Luscombe NM, Ule J. 2010. iCLIP reveals the function of hnRNP particles in splicing at individual nucleotide resolution. Nat Struct Mol Biol 17: 909-915.

Kundel M, Jones KJ, Shin CY, Wells DG. 2009. Cytoplasmic polyadenylation element-binding protein regulates neurotrophin-3-dependent $\beta$-catenin mRNA translation in developing hippocampal neurons. J Neurosci 29: 13630 13639.

Laggerbauer B, Ostareck D, Keidel EM, Ostareck-Lederer A, Fischer U. 2001. Evidence that fragile X mental retardation protein is a negative regulator of translation. Hum Mol Genet 10: 329-338.

Lantz V, Chang JS, Horabin JI, Bopp D, Schedl P. 1994. The Drosophila orb RNA-binding protein is required for the formation of the egg chamber and establishment of polarity. Genes Dev 8: 598-613.
Li Z, Zhang Y, Ku L, Wilkinson KD, Warren ST, Feng Y. 2001. The fragile $\mathrm{X}$ mental retardation protein inhibits translation via interacting with mRNA. Nucleic Acids Res 29: 2276-2283.

Li C, Bassell GJ, Sasaki Y. 2009. Fragile X mental retardation protein is involved in protein synthesis-dependent collapse of growth cones induced by Semaphorin-3A. Front Neural Circuits 3: 11.

Licatalosi DD, Mele A, Fak JJ, Ule J, Kayikci M, Chi SW, Clark TA, Schweitzer AC, Blume JE, Wang X, et al. 2008. HITS-CLIP yields genome-wide insights into brain alternative RNA processing. Nature 456: 464-469.

Lin AC, Tan CL, Lin CL, Strochlic L, Huang YS, Richter JD, Holt CE. 2009. Cytoplasmic polyadenylation and cytoplasmic polyadenylation element-dependent mRNA regulation are involved in Xenopus retinal axon development. Neural Dev 4: 8.

Lin CL, Evans V, Shen S, Xing Y, Richter JD. 2010. The nuclear experience of CPEB: Implications for RNA processing and translational control. RNA 16: 338-348.

Liu J, Schwartz JH. 2003. The cytoplasmic polyadenylation element binding protein and polyadenylation of messenger RNA in Aplysia neurons. Brain Res 959: 68-76.

Livingstone M, Atas E, Meller A, Sonenberg N. 2010. Mechanisms governing the control of mRNA translation. Phys Biol 7: 021001.

Mazan-Mamczarz K, Galban S, Lopez de Silanes I, Martindale JL, Atasoy U, Keene JD, Gorospe M. 2003. RNAbinding protein HuR enhances p53 translation in response to ultraviolet light irradiation. Proc Natl Acad Sci 100: 8354-8359.

McEvoy M, Cao G, Montero Llopis P, Kundel M, Jones K, Hofler C, Shin C, Wells DG. 2007. Cytoplasmic polyadenylation element binding protein 1-mediated mRNA translation in Purkinje neurons is required for cerebellar long-term depression and motor coordination. J Neurosci 27: 6400-6411.

Mee CJ, Pym EC, Moffat KG, Baines RA. 2004. Regulation of neuronal excitability through pumilio-dependent control of a sodium channel gene. J Neurosci 24: 8695-8703.

Mendez R, Richter JD. 2001. Translational control by CPEB: A means to the end. Nat Rev Mol Cell Biol 2: 521-529.

Mendez R, Hake LE, Andresson T, Littlepage LE, Ruderman JV, Richter JD. 2000a. Phosphorylation of CPE binding factor by Eg2 regulates translation of c-mos mRNA. $\mathrm{Na}$ ture 404: 302-307.

Mendez R, Murthy KG, Ryan K, Manley JL, Richter JD. 2000b. Phosphorylation of CPEB by Eg2 mediates the recruitment of CPSF into an active cytoplasmic polyadenylation complex. Mol Cell 6: 1253-1259.

Menon KP, Sanyal S, Habara Y, Sanchez R, Wharton RP, Ramaswami M, Zinn K. 2004. The translational repressor Pumilio regulates presynaptic morphology and controls postsynaptic accumulation of translation factor eIF-4E. Neuron 44: 663-676.

Michel CI, Kraft R, Restifo LL. 2004. Defective neuronal development in the mushroom bodies of Drosophila fragile X mental retardation 1 mutants. J Neurosci 24: $5798-$ 5809.

Mishchenko Y, Hu T, Spacek J, Mendenhall J, Harris KM, Chklovskii DB. 2010. Ultrastructural analysis of 
hippocampal neuropil from the connectomics perspective. Neuron 67: 1009-1020.

Mukherjee N, Corcoran DL, Nusbaum JD, Reid DW, Georgiev S, Hafner M, Ascano MJ, Tuschl T, Ohler U, Keene JD, et al. 2011. Integrative regulatory mapping indicates that the RNA-binding protein HuR couples pre-mRNA processing and mRNA stability. Mol Cell 43: 327-339.

Nakahata S, Katsu Y, Mita K, Inoue K, Nagahama Y, Yamashita M. 2001. Biochemical identification of Xenopus Pumilio as a sequence-specific cyclin B1 mRNA-binding protein that physically interacts with a Nanos homolog, Xcat-2, and a cytoplasmic polyadenylation elementbinding protein. J Biol Chem 276: 20945-20953.

Okano HJ, Darnell RB. 1997. A hierarchy of Hu RNA binding proteins in developing and adult neurons. J Neurosci 17: 3024-3037.

Ostroff LE, Fiala JC, Allwardt B, Harris KM. 2002. Polyribosomes redistribute from dendritic shafts into spines with enlarged synapses during LTP in developing rat hippocampal slices. Neuron 35: 535-545.

Ostroff LE, Cain CK, Bedont J, Monfils MH, Ledoux JE. 2010. Fear and safety learning differentially affect synapse size and dendritic translation in the lateral amygdala. Proc Natl Acad Sci 107: 9418-9423.

Park S, Park JM, Kim S, Kim JA, Shepherd JD, Smith-Hicks CL, Chowdhury S, Kaufmann W, Kuhl D, Ryazanov AG, et al. 2008. Elongation factor 2 and fragile X mental retardation protein control the dynamic translation of Arc/ Arg3.1 essential for mGluR-LTD. Neuron 59: 70-83.

Pascale A, Gusev PA, Amadio M, Dottorini T, Govoni S, Alkon DL, Quattrone A. 2004. Increase of the RNA-binding protein $\mathrm{HuD}$ and posttranscriptional up-regulation of the GAP-43 gene during spatial memory. Proc Natl Acad Sci 101: 1217-1222.

Pascale A, Amadio M, Quattrone A. 2008. Defining a neuron: Neuronal ELAV proteins. Cell Mol Life Sci 65: $128-140$.

Penagarikano O, Mulle JG, Warren ST. 2007. The pathophysiology of fragile x syndrome. Annu Rev Genomics Hum Genet 8: 109-129.

Perycz M, Urbanska AS, Krawczyk PS, Parobczak K, Jaworski J. 2011. Zipcode binding protein 1 regulates the development of dendritic arbors in hippocampal neurons. $J$ Neurosci 31: 5271-5285.

Pieretti M, Zhang F, Fu Y, Warren ST, Oostra BA, Caskey CT, Nelson DL. 1991. Absence of expression of the FMR-1 gene in fragile X syndrome. Cell 66: 817-822.

Pique M, Lopez JM, Foissac S, Guigo R, Mendez R. 2008. A combinatorial code for CPE-mediated translational control. Cell 132: 434-448.

Posner JB, Dalmau J. 1997. Paraneoplastic syndromes. Curr Opin Immunol 9: 723-729.

Quattrone A, Pascale A, Nogues X, Zhao W, Gusev P, Pacini A, Alkon DL. 2001. Posttranscriptional regulation of gene expression in learning by the neuronal ELAV-like mRNAstabilizing proteins. Proc Natl Acad Sci 98: 11668-11673.

Quenault T, Lithgow T, Traven A. 2011. PUF proteins: Repression, activation and mRNA localization. Trends Cell Biol 21: 104-112.

Richter JD. 2007. CPEB: A life in translation. Trends Biochem Sci 32: 279-285.
Richter JD, Klann E. 2009. Making synaptic plasticity and memory last: Mechanisms of translational regulation. Genes Dev 23: 1-11.

Richter JD, Sonenberg N. 2005. Regulation of cap-dependent translation by eIF4E inhibitory proteins. Nature 433: 477-480.

Robinow S, Campos AR, Yao KM, White K. 1988. The elav gene product of Drosophila, required in neurons, has three RNP consensus motifs. Science 242: 1570-1572.

Sabatini DM. 2006. mTOR and cancer: Insights into a complex relationship. Nat Rev Cancer 6: 729-734.

Santoro MR, Bray SM, Warren ST. 2011. Molecular mechanisms of fragile X syndrome: A twenty-year perspective. Annu Rev Pathol 7: 219-245.

Sasaki Y, Welshhans K, Wen Z, Yao J, Xu M, Goshima Y, Zheng JQ, Bassell GJ. 2010. Phosphorylation of zipcode binding protein 1 is required for brain-derived neurotrophic factor signaling of local $\beta$-actin synthesis and growth cone turning. J Neurosci 30: 9349-9358.

Scheetz AJ, Nairn AC, Constantine-Paton M. 2000. NMDA receptor-mediated control of protein synthesis at developing synapses. Nat Neurosci 3: 211-216.

Shiina N, Tokunaga M. 2010. RNA granule protein 140 (RNG140), a paralog of RNG105 localized to distinct RNA granules in neuronal dendrites in the adult vertebrate brain. J Biol Chem 285: 24260-24269.

Shiina N, Shinkura K, Tokunaga M. 2005. A novel RNAbinding protein in neuronal RNA granules: Regulatory machinery for local translation. J Neurosci 25: $4420-$ 4434.

Shiina N, Yamaguchi K, Tokunaga M. 2010. RNG105 deficiency impairs the dendritic localization of mRNAs for $\mathrm{Na}^{+} / \mathrm{K}^{+}$ATPase subunit isoforms and leads to the degeneration of neuronal networks. J Neurosci 30: 1281612830 .

Si K, Giustetto M, Etkin A, Hsu R, Janisiewicz AM, Miniaci MC, Kim JH, Zhu H, Kandel ER. 2003a. A neuronal isoform of CPEB regulates local protein synthesis and stabilizes synapse-specific long-term facilitation in aplysia. Cell 115: 893-904.

Si K, Lindquist S, Kandel ER. 2003b. A neuronal isoform of the aplysia CPEB has prion-like properties. Cell 115: 879-891.

Si K, Choi YB, White-Grindley E, Majumdar A, Kandel ER. 2010. Aplysia CPEB can form prion-like multimers in sensory neurons that contribute to long-term facilitation. Cell 140: 421-435.

Silvera D, Formenti SC, Schneider RJ. 2010. Translational control in cancer. Nat Rev Cancer 10: 254-266.

Siomi H, Siomi MC, Nussbaum RL, Dreyfuss G. 1993. The protein product of the fragile $\mathrm{X}$ gene, FMR1, has characteristics of an RNA-binding protein. Cell 74: 291-298.

Slevin MK, Gourronc F, Hartley RS. 2007. ElrA binding to the $3^{\prime} \mathrm{UTR}$ of cyclin E1 mRNA requires polyadenylation elements. Nucleic Acids Res 35: 2167-2176.

Solomon S, Xu Y, Wang B, David MD, Schubert P, Kennedy D, Schrader JW. 2007. Distinct structural features of caprin-1 mediate its interaction with G3BP-1 and its induction of phosphorylation of eukaryotic translation initiation factor $2 \alpha$, entry to cytoplasmic stress granules, and 
J.C. Darnell and J.D. Richter

selective interaction with a subset of mRNAs. Mol Cell Biol 27: 2324-2342.

Stebbins-Boaz B, Cao Q, de Moor CH, Mendez R, Richter JD. 1999. Maskin is a CPEB-associated factor that transiently interacts with elF-4E. Mol Cell 4: 1017-1027.

Stefani G, Fraser CE, Darnell JC, Darnell RB. 2004. Fragile $\mathrm{X}$ mental retardation protein is associated with translating polyribosomes in neuronal cells. J Neurosci 24: 7272-7276.

Steward O, Levy WB. 1982. Preferential localization of polyribosomes under the base of dendritic spines in granule cells of the dentate gyrus. J Neurosci 2: 284-291.

Sutton MA, Schuman EM. 2006. Dendritic protein synthesis, synaptic plasticity, and memory. Cell 127: 49-58.

Sutton MA, Taylor AM, Ito HT, Pham A, Schuman EM. 2007. Postsynaptic decoding of neural activity: eEF2 as a biochemical sensor coupling miniature synaptic transmission to local protein synthesis. Neuron 55: 648-661.

Szabo A, Dalmau J, Manley G, Rosenfeld M, Wong E, Henson J, Posner JB, Furneaux HM. 1991. HuD, a paraneoplastic encephalomyelitis antigen, contains RNA-binding domains and is homologous to Elav and Sex-lethal. Cell 67: $325-333$.

Tanner DC, Qiu S, Bolognani F, Partridge LD, Weeber EJ, Perrone-Bizzozero NI. 2008. Alterations in mossy fiber physiology and GAP-43 expression and function in transgenic mice overexpressing HuD. Hippocampus 18: $814-$ 823.

Tee AR, Blenis J. 2005. mTOR, translational control and human disease. Semin Cell Dev Biol 16: 29-37.

Tenenbaum SA, Carson CC, Lager PJ, Keene JD. 2000. Identifying mRNA subsets in messenger ribonucleoprotein complexes by using cDNA arrays. Proc Natl Acad Sci 97: 14085-14090.

Tessier CR, Broadie K. 2008. Drosophila fragile X mental retardation protein developmentally regulates activitydependent axon pruning. Development 135: 1547-1557.

Tessier CR, Doyle GA, Clark BA, Pitot HC, Ross J. 2004. Mammary tumor induction in transgenic mice expressing an RNA-binding protein. Cancer Res 64: 209-214.

Theis M, Si K, Kandel ER. 2003. Two previously undescribed members of the mouse CPEB family of genes and their inducible expression in the principal cell layers of the hippocampus. Proc Natl Acad Sci 100: 9602-9607.

Till SM, Li HL, Miniaci MC, Kandel ER, Choi YB. 2011. A presynaptic role for FMRP during protein synthesis-dependent long-term plasticity in Aplysia. Learn Mem 18: 39-48.

Tiruchinapalli DM, Oleynikov Y, Kelic S, Shenoy SM, Hartley A, Stanton PK, Singer RH, Bassell GJ. 2003. Activitydependent trafficking and dynamic localization of zipcode binding protein 1 and $\beta$-actin mRNA in dendrites and spines of hippocampal neurons. J Neurosci 23: 32513261.

Tiruchinapalli DM, Ehlers MD, Keene JD. 2008. Activitydependent expression of RNA binding protein $\mathrm{HuD}$ and its association with mRNAs in neurons. RNA Biol 5: 157-168.

Ule J, Jensen KB, Ruggiu M, Mele A, Ule A, Darnell RB. 2003. CLIP identifies Nova-regulated RNA networks in the brain. Science 302: 1212-1215.
Ule J, Jensen K, Mele A, Darnell RB. 2005. CLIP: A method for identifying protein-RNA interaction sites in living cells. Methods 37: 376-386.

Verkerk AJ, Pieretti M, Sutcliffe JS, Fu YH, Kuhl DP, Pizzuti A, Reiner O, Richards S, Victoria MF, Zhang FP. 1991. Identification of a gene (FMR-1) containing a CGG repeat coincident with a breakpoint cluster region exhibiting length variation in fragile $\mathrm{X}$ syndrome. Cell 65: 905-914.

Vessey JP, Vaccani A, Xie Y, Dahm R, Karra D, Kiebler MA, Macchi P. 2006. Dendritic localization of the translational repressor Pumilio 2 and its contribution to dendritic stress granules. J Neurosci 26: 6496-6508.

Vessey JP, Schoderboeck L, Gingl E, Luzi E, Riefler J, Di Leva F, Karra D, Thomas S, Kiebler MA, Macchi P, et al. 2010. Mammalian Pumilio 2 regulates dendrite morphogenesis and synaptic function. Proc Natl Acad Sci 107: 3222-3227.

Wang DO, Martin KC, Zukin RS. 2010. Spatially restricting gene expression by local translation at synapses. Trends Neurosci 33: 173-182.

Weinlich S, Huttelmaier S, Schierhorn A, Behrens SE, Ostareck-Lederer A, Ostareck DH. 2009. IGF2BP1 enhances HCV IRES-mediated translation initiation via the 3'UTR. RNA 15: 1528-1542.

Wells DG, Dong X, Quinlan EM, Huang YS, Bear MF, Richter JD, Fallon JR. 2001. A role for the cytoplasmic polyadenylation element in NMDA receptor-regulated mRNA translation in neurons. J Neurosci 21: 9541-9548.

Wharton RP, Struhl G. 1991. RNA regulatory elements mediate control of Drosophila body pattern by the posterior morphogen nanos. Cell 67: 955-967.

Wickens M, Bernstein DS, Kimble J, Parker R. 2002. A PUF family portrait: $3^{\prime}$ UTR regulation as a way of life. Trends Genet 18: 150-157.

Wolin SL, Walter P. 1988. Ribosome pausing and stacking during translation of a eukaryotic mRNA. EMBO J 7: 3559-3569.

Wu L, Wells D, Tay J, Mendis D, Abbott MA, Barnitt A, Quinlan E, Heynen A, Fallon JR, Richter JD, et al. 1998. CPEB-mediated cytoplasmic polyadenylation and the regulation of experience-dependent translation of $\alpha$ CaMKII mRNA at synapses. Neuron 21: 1129-1139.

Ye B, Petritsch C, Clark IE, Gavis ER, Jan LY, Jan YN. 2004. Nanos and Pumilio are essential for dendrite morphogenesis in Drosophila peripheral neurons. Curr Biol 14: 314-321.

Zamore PD, Williamson JR, Lehmann R. 1997. The Pumilio protein binds RNA through a conserved domain that defines a new class of RNA-binding proteins. RNA 3: 1421-1433.

Zang JB, Nosyreva ED, Spencer CM, Volk LJ, Musunuru K, Zhong R, Stone EF, Yuva-Paylor LA, Huber KM, Paylor R, et al. 2009. A mouse model of the human Fragile X syndrome I304N mutation. PLoS Genet 5: e1000758.

Zhang C, Darnell RB. 2011. Mapping in vivo protein-RNA interactions at single-nucleotide resolution from HITSCLIP data. Nat Biotechnol 29: 607-614.

Zhang HL, Eom T, Oleynikov Y, Shenoy SM, Liebelt DA, Dictenberg JB, Singer RH, Bassell GJ. 2001a. Neurotrophin- 
RNA-Binding Proteins in the Brain

induced transport of a $\beta$-actin mRNP complex increases $\beta$-actin levels and stimulates growth cone motility. Neuron 31: $261-275$.

Zhang YQ, Bailey AM, Matthies HJ, Renden RB, Smith MA, Speese SD, Rubin GM, Broadie K. 2001b. Drosophila fragile X-related gene regulates the MAP1B homolog Futsch to control synaptic structure and function. Cell 107: 591-603.

Zhu H, Hasman RA, Barron VA, Luo G, Lou H. 2006. A nuclear function of Hu proteins as neuron-specific alternative RNA processing regulators. Mol Biol Cell 17: 5105-5114. 


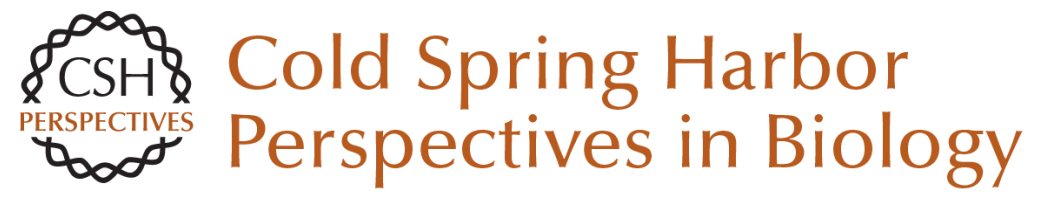

\title{
Cytoplasmic RNA-Binding Proteins and the Control of Complex Brain Function
}

\author{
Jennifer C. Darnell and Joel D. Richter
}

Cold Spring Harb Perspect Biol 2012; doi: 10.1101/cshperspect.a012344 originally published online June 20, 2012

\section{Subject Collection Protein Synthesis and Translational Control}

Tinkering with Translation: Protein Synthesis in

Virus-Infected Cells

Derek Walsh, Michael B. Mathews and lan Mohr

Translational Control in Cancer Etiology

Davide Ruggero

\section{A Molecular Link between miRISCs and Deadenylases Provides New Insight into the Mechanism of Gene Silencing by MicroRNAs Joerg E. Braun, Eric Huntzinger and Elisa Izaurralde}

Imaging Translation in Single Cells Using Fluorescent Microscopy

Jeffrey A. Chao, Young J. Yoon and Robert $H$. Singer

mRNA Localization and Translational Control in Drosophila Oogenesis Paul Lasko

P-Bodies and Stress Granules: Possible Roles in the Control of Translation and mRNA Degradation Carolyn J. Decker and Roy Parker

Protein Secretion and the Endoplasmic Reticulum Adam M. Benham
Toward a Genome-Wide Landscape of

Translational Control

Ola Larsson, Bin Tian and Nahum Sonenberg

The Current Status of Vertebrate Cellular mRNA IRESs

Richard J. Jackson

Principles of Translational Control: An Overview John W.B. Hershey, Nahum Sonenberg and Michael B. Mathews

Regulation of mRNA Translation by Signaling Pathways

Philippe P. Roux and Ivan Topisirovic

The Mechanism of Eukaryotic Translation Initiation: New Insights and Challenges Alan G. Hinnebusch and Jon R. Lorsch

Single-Molecule Analysis of Translational Dynamics Alexey Petrov, Jin Chen, Seán O'Leary, et al.

Cytoplasmic RNA-Binding Proteins and the Control of Complex Brain Function Jennifer C. Darnell and Joel D. Richter

For additional articles in this collection, see http://cshperspectives.cshlp.org/cgi/collection/

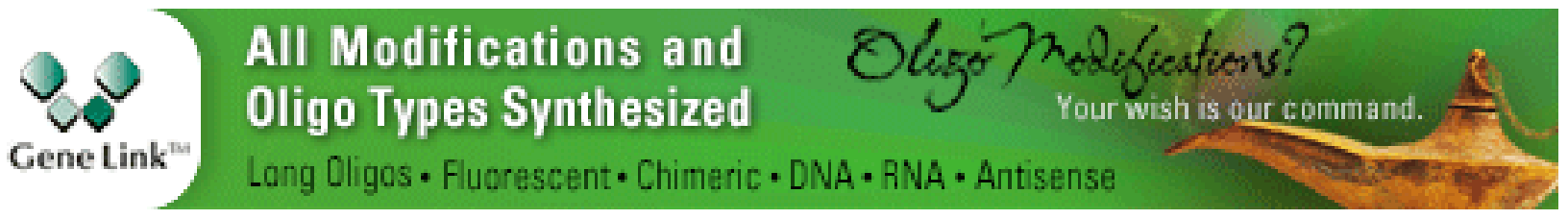




\section{From Cis-Regulatory Elements to Complex RNPs and Back}

Fátima Gebauer, Thomas Preiss and Matthias W. Hentze
The Elongation, Termination, and Recycling Phases of Translation in Eukaryotes Thomas E. Dever and Rachel Green

For additional articles in this collection, see http://cshperspectives.cshlp.org/cgi/collection/

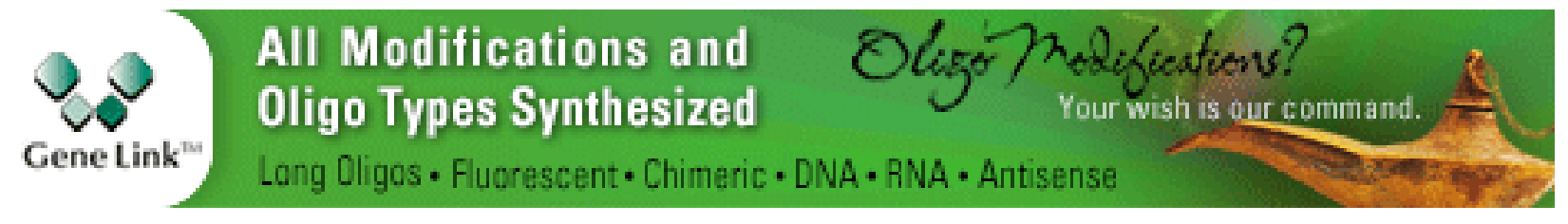

Copyright @ 2012 Cold Spring Harbor Laboratory Press; all rights reserved 